\title{
Magazines Zig-Zag: reportajes gráficos y alteridad en torno al indígena de la nueva frontera norte chilena (1905-1930)
}

\section{Magazines Zig-Zag: graphic reports and otherness on the indigenous population of the new frontier northern Chile (1905-1930)}

Rodrigo Ruz Zagal ${ }^{1}$ https://orcid.org/0000-0002-7474-6441

Luis Galdames Rosas ${ }^{2}$ https://orcid.org/0000-0003-3969-3214

Michel Meza Aliaga ${ }^{3}$ https://orcid.org/0000-0001-8780-6215

${ }^{1}$ Departamento de Ciencias Históricas y Geográficas, Universidad de Tarapacá. 18 de septiembre 2222. Arica, CHILE. Email: rruz@uta.cl

${ }^{2}$ Departamento de Ciencias Históricas y Geográficas, Universidad de Tarapacá. 18 de septiembre 2222. Arica, CHILE. Email: lgaldame@uta.cl

${ }^{3}$ Programa de Doctorado en Estudios Latinoamericanos, Universidad de Chile. Capitán Ignacio Carrera Pinto 1025. Santiago, CHILE. Email: mmezaa@uta.cl

\section{Resumen}

Se sostiene que las revistas magazinescas Zig-Zag y Sucesos, publicadas bajo el sello editorial Zig-Zag, entre 1905 y 1930, por medio de sus reportajes y fotorreportajes, vehiculizaron ideas respecto de la sociedad y culturas indígenas de la nueva frontera norte chilena, así como de su vecindad andina (surperuana y boliviana), cargadas de elementos y juicios valorativos negativos asociados al fuerte componente indígena de la región, contribuyendo a crear un imaginario pernicioso en torno a estos, circulante en el Chile central post Guerra del Pacífico (1879-1883).

Palabras claves: nacionalismos, magazines, población indígena.

\begin{abstract}
It is argued that the magazines Zig-Zag and Sucesos, published under the imprint ZigZag between 1905 and 1930, through their reports and photojournalism spreaded ideas about society and indigenous cultures of Chile's new northern border, as well as its Andean neighborhood (southern Peru and Bolivia), loaded with negative elements and value judgments, all of them related to the large indigenous population of the region, contributing to create a negative imaginary around them in central Chile after the Pacific War (1879-1883).
\end{abstract}

Keywords: nationalisms, magazines, indigenous population.

Recibido: 21 septiembre 2016. Aceptado: 8 diciembre 2016 


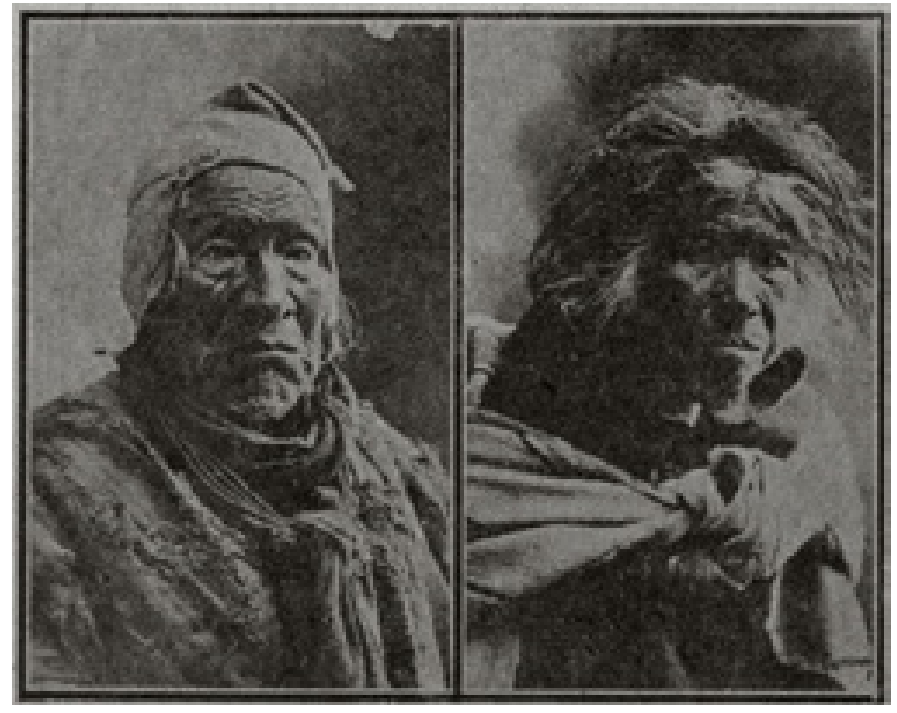

Figura 1. “Tipos tacneños”. Revista Sucesos 775, 02 de Agosto de 1917.

\section{Introducción}

La Figura 1 acompaña la nota periodística aparecida a principios del siglo XX en la revista Sucesos, precursora del género magazinesco en Chile. En ella se retrata a dos personas, un hombre y una mujer de edad avanzada ataviados a la usanza andina tradicional, con un sombrero (ch'uyo) y un textil de carga (awayu) respectivamente, que, si asumimos las actuales fronteras nacionales, bien podrían pertenecer al norte de Chile o a la meseta nuclear de los Andes peruanos, bolivianos o ecuatorianos, aunque también al noroeste argentino.

A la fotografía le antecede un título y le sigue un comentario que permite situar al lector en el entonces "nuevo norte chileno". La nota se titula "Tipos tacneños" y le asiste el siguiente texto: "He aquí dos tipos tacneños: marido y mujer. Nuestro corresponsal fotográfico, señor Gutiérrez nos dice que estos tipos son frecuentes en Tacna... jhay entonces allí para curarse del hipo!". ${ }^{1}$

Sin decirlo de forma explícita, el autor refiere a un tipo de hilaridad existente en el Chile central de co-

1 Texto que permitiría otorgar un significado preciso a la imagen eliminando el resto de significados posibles, orientando así nuestra intelección hacia un sentido determinado (Barthes, 1986). mienzos del siglo XX, el cual representa a nuestro juicio mucho más que un negro sentido humorístico, pudiendo reflejar lo que en historia cultural se define como "espíritu de época", "clima de opinión" o "atmósfera intelectual", ${ }^{2}$ categorías que para efectos de nuestro análisis esconden tras de sí una estructura de sentimientos, afectos y consonancias necesarias de profundizar considerando que caracterizarían a ciertos colectivos humanos definiendo sus identidades y alteridades (Krotz, 1994).

La anexión del sur peruano (Tarapacá, 1883 y Arica, 1929) y el departamento Litoral boliviano (1904) a la soberanía chilena post Guerra de Pacífico (18791883), aún exhibe problemáticas visibles en la sociedad fronteriza y nacional contemporánea, que guardan relación con resabios de este viejo episodio

2 Categorías que convergen en lo que dice relación con la fuerza cultural dominante del espacio de tiempo estudiado. En otras palabras, nos referimos a las ideas hegemónicas del período, entendiendo que "hegemonía no equivale a pensamiento mayoritario; significa simplemente que esa idea goza de un prestigio, de una consideración, especialmente en los medios intelectuales, reverberando este prestigio en las opiniones más comunes" (Ribas y Cortés, 1998, p. 13). En este sentido, los medios de comunicación no son siempre los creadores de la opinión pública, sino que interactúan con otros flujos de ideas que atraviesan el cuerpo social y que son puestos en circulación a través de la prensa. 
bélico y que han traspasado la también vigente dimensión político-diplomática, instalándose a nivel de cultura, ideología e identidades y su consecuentes alteridades, siendo una suerte de herencia que de una manera u otra afecta las relaciones sociales y culturales del vecindario andino actual (Ruz et al., 2015).

Lo anterior, tomando en consideración que el recurso documental utilizado para activar esta discusión "Tipos Tacneńos" posee tras de sí un fuerte contenido ideológico que, solapado en el humor, da cuenta de los límites, tolerancia o simpatía respecto de la hilaridad sugerida en la nota, que para el caso, es la referencia a la supuesta fealdad de las personas indígenas fotografiadas y su condición de peruanos-tacneños mirados desde una perspectiva chilena. Estas características negativas son extendidas en los contenidos de magazines a otras expresiones de etnicidad y cualidades culturales (costumbres, tradiciones), permitiendo que los factores negativos señalados jugaran un rol importante en los discursos de nación e identidad nacional chilena.

Sostenemos que sobre el análisis de la totalidad de registros referidos a la situación indígena del sur peruano, boliviano y nuevo norte chileno expresados por los medios de comunicación nacionales, concentrados en la principal editorial chilena de la época como lo fue Zig-Zag, ${ }^{3}$ es posible dar cuenta de la verosimilitud de estas ideas y atributos negativos respecto de la población indígena nortina. Esto es, la posibilidad de que este imaginario haya sido aceptado en el Chile de comienzos del siglo XX, constituyendo parte de la imaginación en la comunidad chilena respecto al nuevo componente nacional representado por la población nortina de ascendencia mayoritariamente aymara y quechua.

Consideramos a los productores de notas y reportes que tuvieron como caja resonante a los medios de comunicación chilenos y, por ende, parte de la opinión pública, como portadores de una idea de comunidad chilena $-y$ no chilena- inseparable de

3 Este artículo se realizó sobre la revisión de la totalidad de publicaciones Zig-Zag y Sucesos publicadas entre los años 1905 y 1930 . De estas, 108 registros de fotorreportajes referentes a la situación indígena de la "nueva" frontera norte chileno-peruana fueron cubiertos por la revista Sucesos y 63 por Zig-Zag. su forma de ver el mundo, el que fue plasmado en sus notas y reportes periodísticos, característica que explicaría la representación ajena del norte, distante del acostumbrado entorno y cultura chilena manifiesta por el espacio urbano del centro del país o el carácter rural central y sureño del Chile de comienzos del siglo XX (Subercaseaux, 2010; Dümmer, 2014).

Imposible dejar de observar el escenario que a nivel de filosofía política y económica predominaba en el Chile de la época: el positivismo político-jurídico y el liberalismo económico respectivamente, ambas ideas naturalizadas en la élite gobernante y defensoras acérrimas del ideal de progreso acuñado desde la mitad del siglo XIX, que como principal cualidad funcional a nuestra investigación proponía un desmarque de la utopía panamericanista y de sus ataduras telúricas, poniendo como paradigma al progreso en oposición al "retraso" producido por las inercias propias de la vecindad latinoamericana (y andina). Este aspecto no es menor, considerando que esta forma de entender y administrar el país habría justificado la Guerra del Pacífico (McEvoy 2007 y 2010), argumento que con matices regionales se habría proyectado hasta el siglo XX producto de la extensión del conflicto por la situación de incertidumbre en la definición de la nueva frontera norte chileno-peruana reflejada en el escenario de Tacna y Arica (Galdames et al., 2014).

Los medios de comunicación en la complejidad de sus estructuras (corresponsalías, editoriales y línea editorial) permiten entrever la forma de entender la nación desde una perspectiva subjetiva, pero también atravesada por los elementos estables de la estructura de una nación, lo que en teoría puede definirse como la ingeniería deliberada de las autoridades y las élites para conformar una nación como una comunidad a través de instrumentos que operarían muchas veces desde la perspectiva simbólica, implicando la creación de una ideología por medio de una serie de signos y mitos emotivos, pero también como estructura formal a partir del vínculo cívico-ciudadano y el campo del derecho positivo (Smith, 2000; Hobsbawm y Ranger, 2002). 
Perspectivas de análisis con orientación históricocultural se han concentrado en las aperturas dejadas por esta última nomenclatura, profundizando en los aspectos que posicionan tanto a la cultura representada como a los artefactos o símbolos que se supone los representan o espejan, sin descuidar los contextos en que son producidos y semantizados, con objeto de entender la forma en que los colectivos culturales se identifican o distancian del influjo ideológico dominante, construyendo identidad o alteridad (Galdames et al., 2014; Ruz et al., 2015, 2016).

Esta mirada exige el conocimiento de una atmósfera que enmarca un acontecimiento e implica acceder a un intersticio difícil de objetivar en cualquier discusión con tradición historiográfica, siendo necesaria la apertura a lo que las corrientes históricas de nuevo cuño han denominado como sistemas de representación. ${ }^{4}$

Estos permiten permear las estructuras hegemónicas que normalmente caracterizan o condicionan la producción de un registro documental, otorgando visibilidad a las prácticas sociales y culturales a partir del análisis de cuerpos de significados materializados a través del lenguaje. ${ }^{5}$ Es esta materialización la que representa a sujetos que participan de una época y cultura determinadas (Angenot, 2010).

El uso de estos códigos como "visualizadores" de elementos poco aprehensibles considera también la necesidad de indicar -y estar advertido- de sus artefactualizaciones y manipulaciones; situación siempre presente al momento de abordar temáticas que vinculan la presencia de imaginarios en contextos nacionalistas.

La construcción de una discursividad de corte patrio y nacionalista predominante en el Chile decimonónico ha dado cuenta de su temprana aparición en el contexto de la Guerra contra la Confederación Perúboliviana, momento en que se consagra una primera postura (Cid, 2009; Arellano, 2011) y su continui-

4 Considerado como el conjunto de códigos que "leídos" y decodificados (organizados, agrupados y clasificados) adquieren sentido y significado para el colectivo que los interpreta (Hall, 1997).

5 En sus diversos soportes como escrito, visual o auditivo (Hall, 1997). dad en el ambiente previo y durante el desarrollo de la Guerra del Pacífico (Rubilar, 2010; McEvoy, 2012a y b; Arellano, 2012; Ibarra, 2015). A partir de entonces se habría instalado a nivel de ideas operantes la supuesta superioridad chilena ante Perú y Bolivia (Subercaseaux 2010), las que tendrían un período de mayor extensión y presencia en el país debido a la prolongación del conflicto en el Norte Grande chileno a causa de la indefinición soberana de Tacna y Arica (Skuban, 2007; Galdames et al., 2014; Ruz et al., 2015, 2016).

Esta investigación ahonda en el período en que las diferencias entre la vecindad andina regional, que hasta antes de la guerra conformaba un área relativamente homogénea y con una cultura e historia más o menos común, comienza a diferenciarse a partir del influjo discursivo y la instalación de ideas e imaginarios que cimientan un escenario de identificación, pero también de alterización o diferenciación.

\section{Reportes periodísticos y construcción de alteridades}

Los medios periodísticos han sido recurrentemente utilizados por colectivos e instituciones interesadas como vehículos de persuasión y considerados como un elemento de influencia en diversos circuitos de opinión (Ossandón y Santa Cruz, 2005).

Lejos de que esta característica sea considerada un sesgo metodológico, observaremos a los medios como visualizadores de la forma en que el nuevo norte chileno, sus habitantes y cultura nativa comienzan a ser conocidos por la comunidad nacional del centro de Chile, aceptando el supuesto teórico que en sus textos e imágenes se encuentran rasgos de ideas operantes que componen el imaginario nacional chileno de principios del siglo XX (Subercaseaux, 2010).

En este contexto, el siglo XX en Chile fue para los medios de comunicación impresos un importante momento para incorporar nuevas tecnologías, formatos de administración editorial con característica de empresa y el abordaje de temáticas emergentes que fueron dejando atrás una determinada cultura y precaria técnica de imprenta instalada desde 
mediados del siglo XIX en el país (Santa Cruz, 2002; Montealegre, 2008; García y Escobar, 2012).

El magazine como revista se proyectó como un importante género periodístico de carácter misceláneo, abarcador de una diversidad de temas, tanto nacionales como internacionales, sin establecer una jerarquización entre ellos (Ossandón y Santa Cruz, 2005). Se caracterizó especialmente por el uso profuso de la imagen, relegando muchas veces el discurso textual a un segundo plano, lo cual se debió tanto a una estrategia de tipo comercial como a que en el período estudiado la imprenta contaba con los medios técnicos para reproducir imágenes de buena calidad en forma masiva (Santa Cruz, 2002; Montealegre, 2008).

Esta diversidad temática, sumada al importante rol asignado a la imagen en las distintas publicaciones, convirtieron al magazine chileno en un artefacto cultural que jugó un importante papel en la complejización y difusión de los imaginarios sociales, así como también en la ampliación de la experiencia colectiva y cotidiana de los lectores. Desde principios del siglo XX, difunden las características y cualidades geográficas, históricas y culturales del mundo y principalmente del país, haciéndolos "familiares" ante su público (Freund, 2014).

\section{Editorial Zig-Zag y sus magazines}

La revista precursora del magazine en Chile fue Sucesos, fundada en septiembre de 1902 en la ciudad de Valparaíso, publicada por la imprenta y litografía Universo de propiedad del empresario alemán Guillermo Helfmann. Su orientación fue la de una revista de actualidad que abarcaba temas políticos, sociales, culturales, deportivos y policiales. Fue publicada durante treinta ańos sin interrupciones hasta el año 1932.

La revista $Z i g-Z a g$ es quizás una de las más representativas del género magazinesco en Chile. Fundada en Santiago en 1905 por el propietario del diario El Mercurio, Agustín Edwards Mac Clure, tuvo un fuerte acento en la comunicación gráfica refrendada por la calidad de las imágenes que contenía cada número.
Ambos magazines fueron diseñados preferentemente para ser vistos y luego leídos (Santa Cruz, 2002), mostrando imágenes que visibilizaron fenómenos y realidades que hasta antes de la existencia de este formato se reducían a lo que la prensa eminentemente escrita pudiera provocar en la imaginación de sus lectores. El magazine al hacer visible lo imaginado fue crucial en la circulación de un sentido social (Ossandón y Santa Cruz, 2005), transformando a la revista en un poderoso artefacto cultural que ancló e hizo circular ideas operantes e imaginarios sociales, especialmente en lo que se refiere a la construcción de la identidad nacional y su consecuente diferenciación hacia las primeras décadas del siglo XX (Rinke, 2002).

\section{Imagen y alteridad del indígena del norte chileno}

La exhibición del espacio septentrional del país en Zig-Zag fue relevante; aspecto que la historiografía chilena poco ha desarrollado, salvo contadas excepciones (Cornejo, 2012; Leiva, 2015; Ruz et al., 2016).

Respecto a la situación de la población indígena que ha ocupado tradicionalmente el espacio nortino de Chile, las investigaciones recientes han dado cobertura preferente a su representación visual a través de la fotografía (Alvarado y Möller, 2011, 2012; Alvarado, 2016; Bajas y Mege, 2012; Maturana, 2012; Bajas, 2016). En general la tesis relevante de este enfoque da cuenta de su sometimiento a procesos de alterización visual-fotográfica, construida y escenificada, aunque compartida en lo referido al acto fotográfico consensuado entre las partes, pero hegemonizado por una de ellas (Alvarado, 2016). En este tenor, la fotografía indígena posee matices de aparición y socialización de imágenes según momentos en los que la presión política ejerció mayor influencia respecto de su necesidad de mostrar o invisibilizar sus nuevas fronteras nacionales en expansión, principalmente durante el siglo XIX, situación a la que no escapó el norte del país a propósito de su "nueva" frontera que se encontraba aún en proceso de constitución bien entrado el siglo XX. 
Un vehículo importante para dar a conocer esta nueva realidad fueron los medios de comunicación periodísticos, que como lo hemos señalado, vinieron a revolucionar el escenario mediático en Chile, complejizando la forma en que la comunidad se percibió como componente de un colectivo nacional, en especial en lo que respecta a la forma como la sociedad del "Chile tradicional" comienza a conocer los nuevos territorios integrados a la soberanía nacional, situación que dejaría en evidencia un proceso de choque cultural más o menos asociado a ciertos elementos de cuńo integrador expresados en el nacionalismo exacerbado tanto en los espacios de frontera como en el centro chileno, en el contexto del ya mencionado conflicto post Guerra del Pacífico.

\section{Editorial Zig-Zag: constructora de la otredad}

El desarrollo de contenidos relativos a la situación nacional chilena hizo que progresivamente los espacios fronterizos alejados del centro del país comenzasen a ser cubiertos y abordados por los medios santiaguinos y porteños (Cornejo, 2012; Ruz et al., 2016). A la vez el discurso mediático visual y escritural sugiere la construcción de un ideario nacional elaborado desde la propia experiencia nacional chilena, o bien desde el desconocimiento de las características de los nuevos espacios regionales componentes de la nación y su vecindad andina.

Por ello se supone que la construcción de una idea del nuevo norte y su población indígena respondió a estereotipos prejuiciosos, en su mayoría negativos, instalados en el centro chileno, en los cuales habrían primado e influido el contexto que enmarcaba la situación nacional asociada a la celebración del Centenario de la independencia colonial, momento exuberante en la transmisión de un concepto de orden, progreso y modernidad teóricamente existente en Chile, discurso visible y presente en la oligarquía nacional y su proyecto nacional $(\mathrm{Su}-$ bercaseaux, 2010), y del que los nuevos terrorios no formaban parte. A esto se sumaba la existencia del paradigma de "raza chilena" como elemento integrador del imaginario nacional, en donde la idea del "roto" chileno se habría perfilado como un ícono funcional y aglutinante de valores nacionales (Subercaseaux, 2007, 2010; Cid, 2009).

A esto se asocia el predominio de creencias a nivel biológico-científico y cultural de la época en torno a la existencia de una "raza chilena" concebida biológicamente como una raza blanco-mestiza (Palacios, 1904), homogénea y uniforme (Larraín, 2008), de rasgo psicológico patriarcal, masculina y por lo tanto guerrera (Mc Evoy, 2012a y 2012b). En el ámbito cultural y social, en tanto, esta idea se asocia al paradigma de la civilización y la modernidad, tratando de equipararse, a nivel discursivo, con las naciones europeas y, a la vez, distanciándose del resto de los países latinoamericanos, asociados, dentro del imaginario eurocentrista que dominaba la escena intelectual y política del período, a la incivilización (barbarie) y el retraso.

Ahora bien, aun cuando el concepto de "raza chilena" careció de un correlato objetivo con la realidad nacional, este fue asumido de manera acrítica por gran parte de la población (Subercaseaux, 2010), ya que, homologado al concepto de nación, se transformó en un verdadero "sistema de significación" (Arellano, 2012) que tuvo una presencia manifiesta en los discursos periodísticos, intelectuales, políticos, sanitarios, patrióticos, militares y educacionales del período en cuestión. En su conjunto, estos discursos habrían cumplido la función tanto de generar la adherencia a la causa nacional por parte de los chilenos -es decir, afianzar un "nosotros"-, así como también de establecer una diferencia con respecto a los "otros" ubicados en la vereda opuesta al paradigma, respondiendo a un patrón desajustado del discurso dominante en donde se encontrarían las características contrarias al ideal hegemónico.

Una manifestación de lo anterior se puede apreciar en la publicidad de la imprenta y litografía Universo, una de las principales imprentas porteńas de principios del siglo XX y que, desde 1919, pasa a ser parte de la editorial Zig-Zag (Ossandón y Santa Cruz, 2005). En esta propaganda (Figura 2), que contrasta a un robusto obrero blanco con un indígena, se plantea la distinción entre el paradigma occidental modernizador de carácter industrial y el no occidental-indio. Su intención se hace más explícita aún con el texto que interpela directamente al lector: “¿Cuál de estos dos ciudadanos prefiere Ud.?”. 


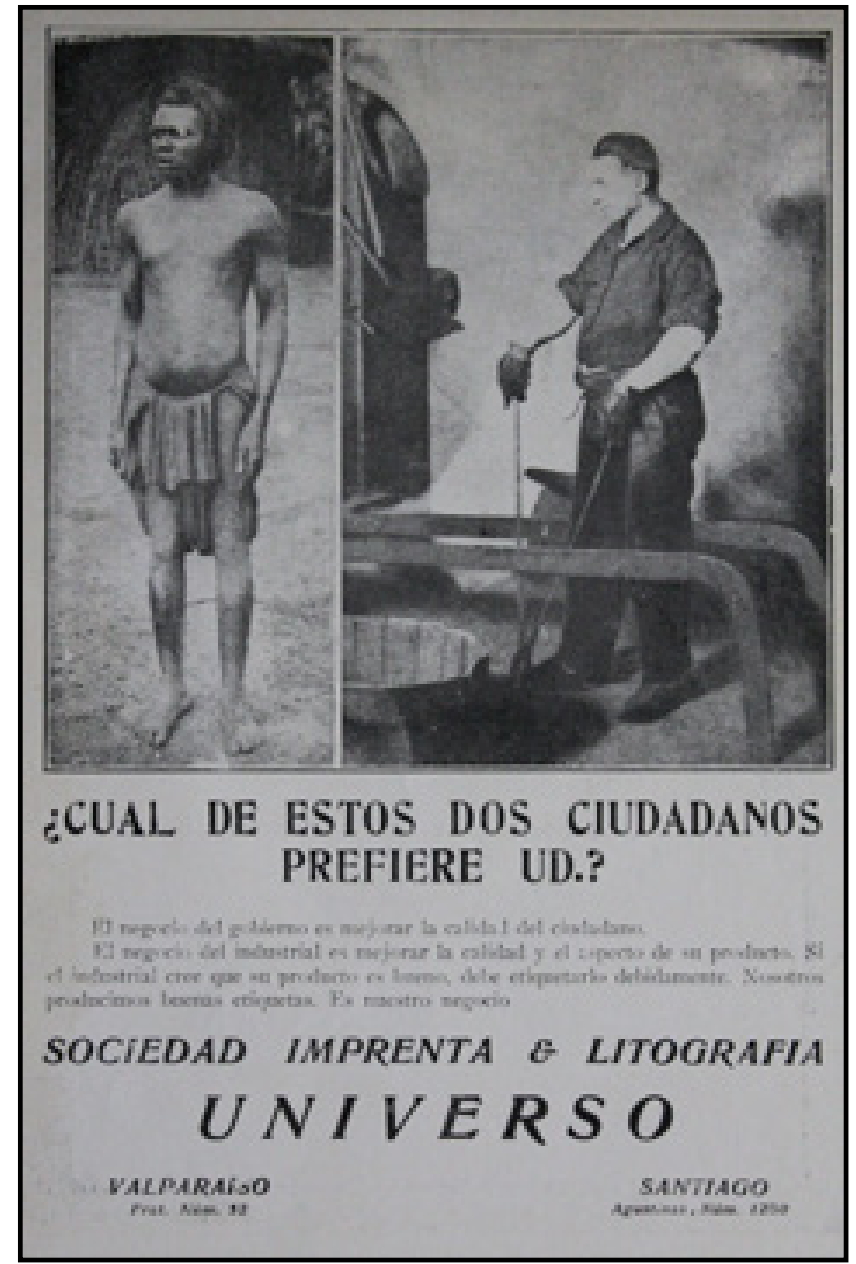

Figura 2. “¿Cuál de estos dos ciudadanos prefiere Ud.?”. Revista Sucesos núm. 977, 26 junio 1921.

Si bien en la Figura 2 se representa a un indígena -se presume- amazónico ${ }^{6}$ que escapa a la situación del componente indígena dentro de los márgenes territoriales chilenos, el carácter de la publicación y dirección editorial ampliamente desarrolla la extensión de esta idea de retraso hacia las comunidades indígenas del sur chileno. Para el caso mapuche, el reportaje "Un pueblo moribundo", aparecido en el número 761 de 1917 (entre otros), se refiere a la realidad mapuche como compuesta por grupos humanos en decadencia, extendiendo de esta forma el sombrío vaticinio continental al escenario nacional (Figura 3). Esta situación también se extiende a los

6 También se hicieron reportajes a comunidades indígenas brasileñas, ecuatorianas, paraguayas y argentinas. pueblos del extremo sur chileno -“Una raza que se extingue”- (Figura 4), a lo que se debe agregar una crónica mordaz y despreciativa hacia el mundo indígena sureño.

La cobertura hacia la vecindad andina (Perú, Bolivia) y su variado escenario multiétnico tuvo un tinte menos explícito y virulento en cuanto su tono y expresión que lo desplegado hacia el componente indígena inserto dentro de los límites tradicionales del país. En ese caso las crónicas y reportajes concentran parte importante de su interés en la exposición del pasado prehispánico, vinculando "lo indio" de ambos países al pasado imperial incaico y tiwanacota, es decir, refiriendo a la ancestralidad y pasado glorioso de un horizonte "clásico" de desarrollo cultural 


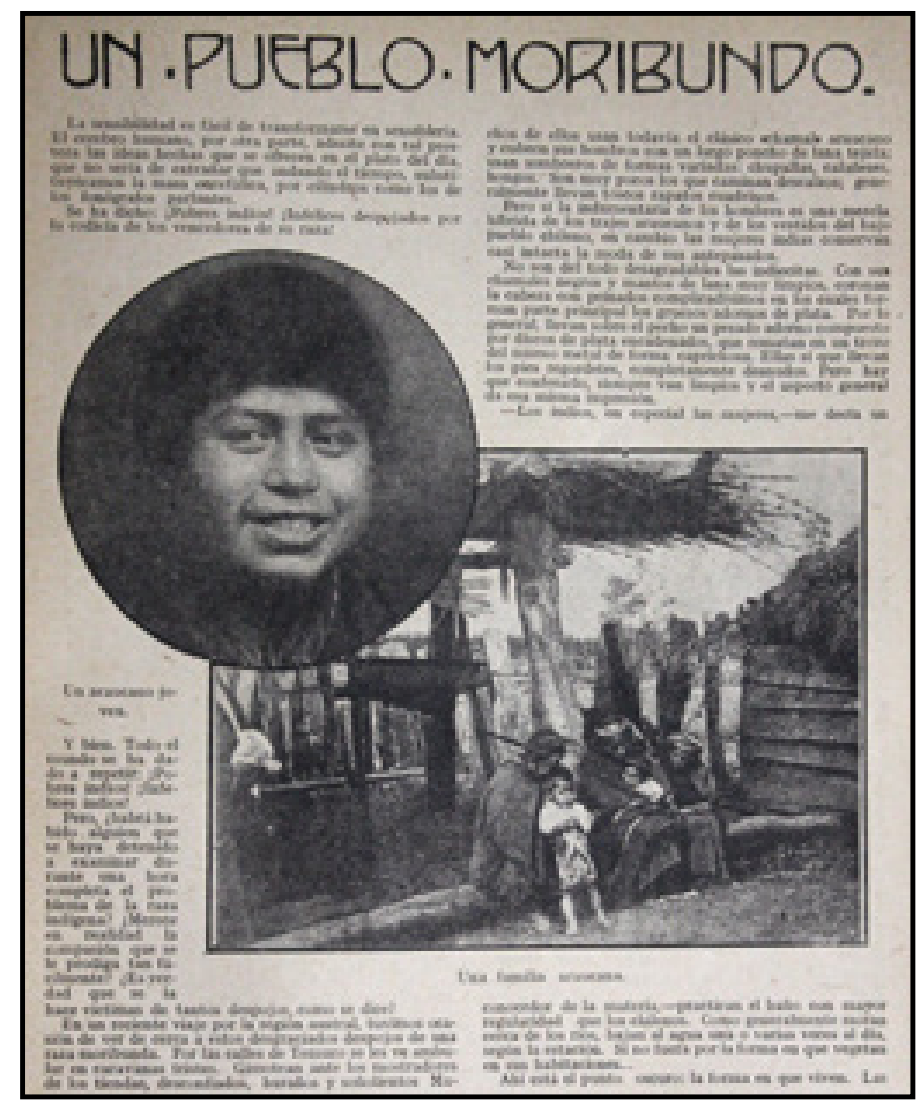

Figura 3. "Un pueblo moribundo”. Revista Sucesos núm. 761, 26 abril 1917.

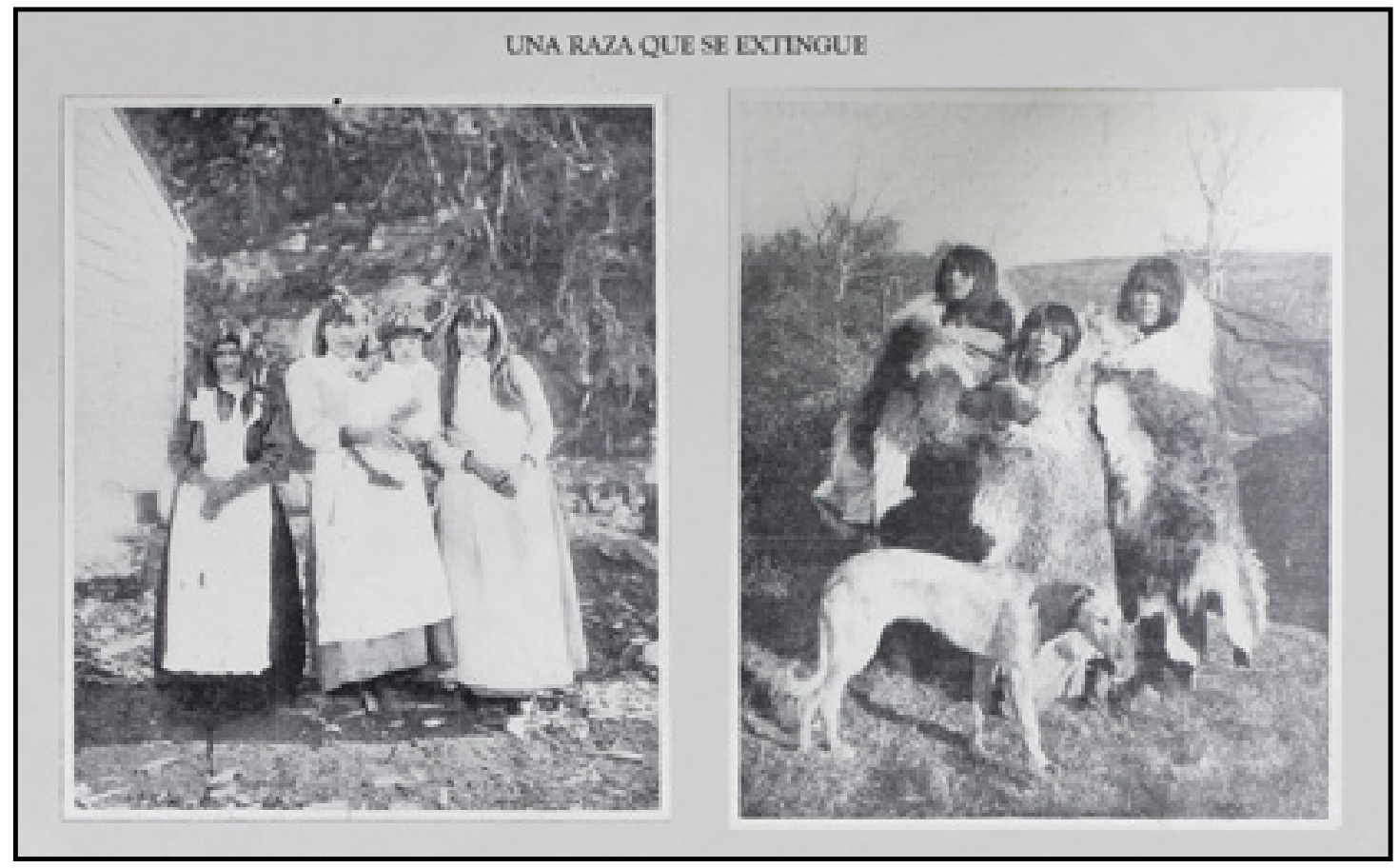

Figura 4. "Una raza que se extingue”. Revista Zig-Zag núm. 101, 27 enero 1907. 
y material, desanclado de la contemporaneidad del indígena de comienzos del siglo XX (Figuras 5 y 6 ). Allí se destaca la monumentalidad de sitios arqueológicos, los que por lo demás llamaban la atención a nivel mundial, Tiwanaku, Cusco y Machu Picchu, como objetos de aprecio seguramente orientado al lector letrado y consumidor de noticias referentes a descubrimientos que para la época marcaban el quehacer científico.

La visibilidad del indígena contemporáneo peruano y boliviano en los magazines expone únicamente relaciones alusivas a "tipos fronterizos", "tipos de provincia" o "tipos populares" que normalmente acercaban al lector a lo advertido por el corresponsal o a lo editado por la revista respecto de la realidad social y étnica de espacios desconocidos a los que se daba cobertura. En el caso de los "tipos", los sujetos expuestos son anónimos, sin identidad y como parte de un mundo ajeno respecto de quien realiza el registro, "pintoresco", característica que se hará extensible a los sujetos indígenas del nuevo norte chileno (Figuras 1 y 7 ).

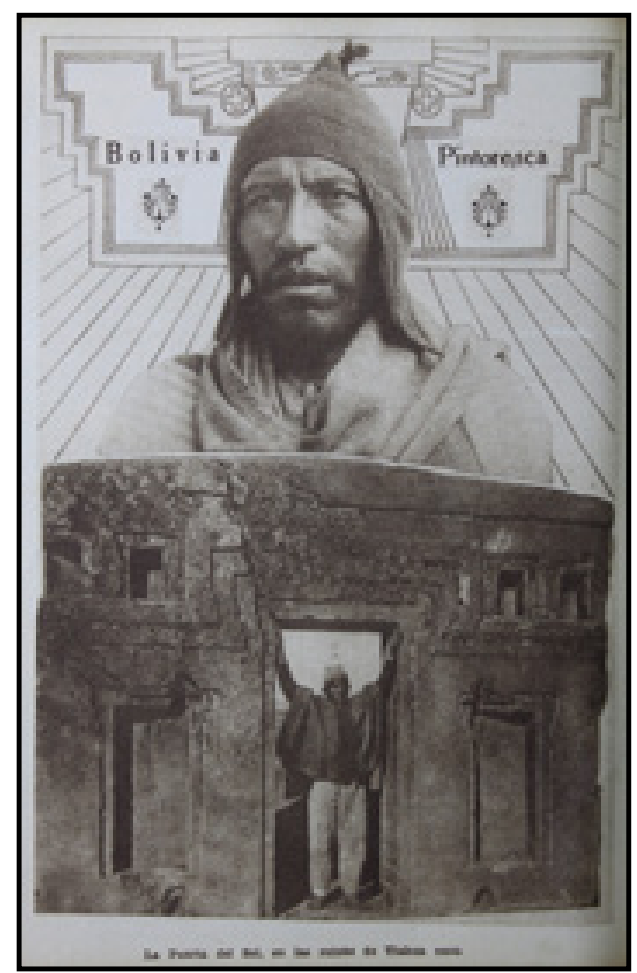

Figura 5. "Bolivia pintoresca”. Revista Zig-Zag núm. 1014, 26 julio 1924.

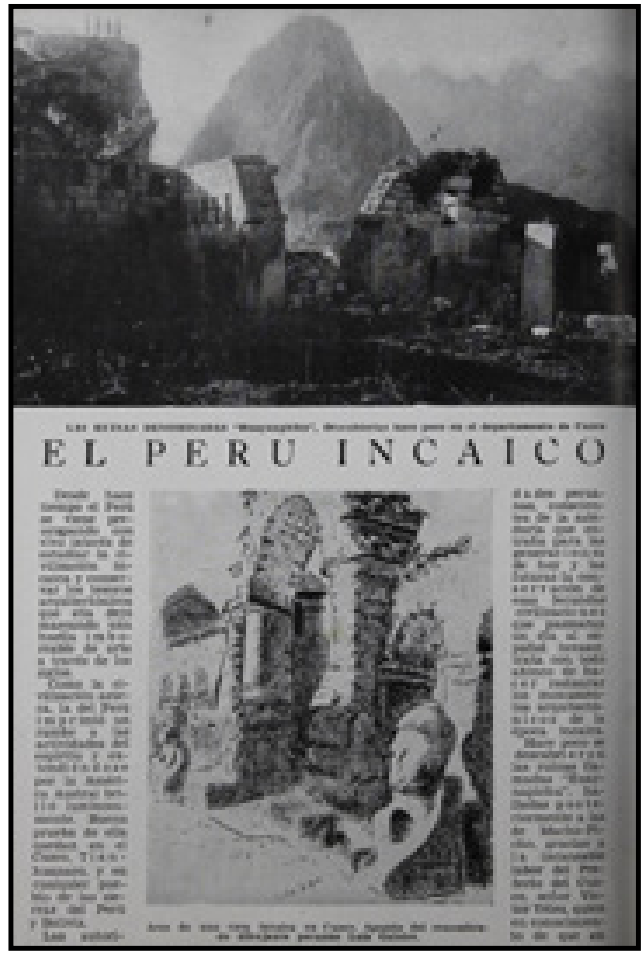

Figura 6. "El Perú incaico". Revista Zig-Zag núm. 1247, 12 enero 1929.

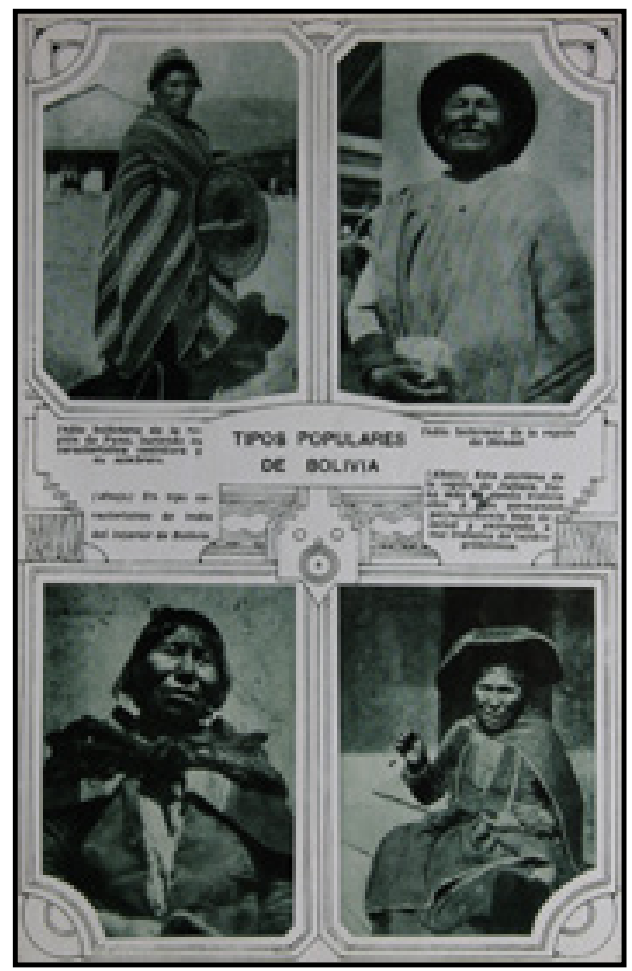

Figura 7. "Tipos populares de Bolivia”. Revista Zig-Zag núm. 1335, 20 septiembre 1930 


\section{El nuevo norte: fealdad y deshumanización}

Siguiendo la tónica mordaz respecto del componente indígena localizado dentro del país, la insinuación de una fealdad indígena expresada en las revistas chilenas sobre el nuevo componente humano ubicado en la frontera chileno-peruana (Figura 1) se construye a partir del ejercicio de oposición a una hermosura, no mencionada y supuestamente depositada en lo no peruano y no indígena: en lo occidental (Figura 2); esto considerando a su vez que Zig-Zag como editorial tenía una fuerte orientación a satisfacer los gustos de la élite metropolitana chilena, la que poseía un capital cultural que

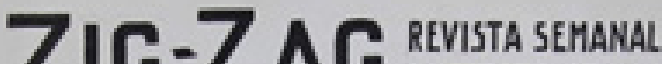

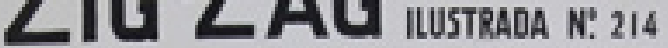

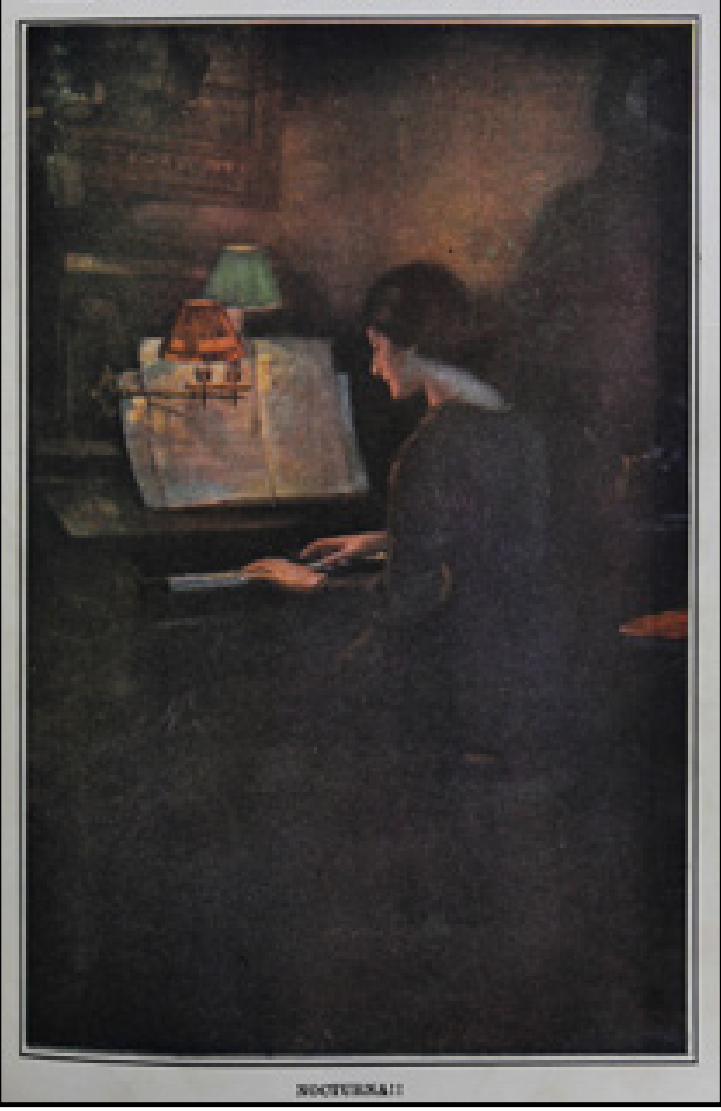

Figura 8. “¡Nocturna!”. Revista Zig-Zag núm. 214, 27 marzo 1909. buscaba acceder a una "alta cultura" europea y nacional, centrada especialmente en la obtención de goce estético en las artes como la pintura, poesía y literatura. Esta característica del sello editorial exigía al magazine una amplia cobertura a estas artes, abordándolas en diversas secciones, las que eran matizadas con contenidos locales y características regionales y de provincia, lo que permitía acceder en un mismo número al canon estético de belleza occidental (Figura 8) y a la de la población indígena andina (Figura 9). Esta oposición visual sumada al anclaje textual, normalmente enfático respecto de las cualidades negativas o incomprensión de una cultura no occidental (andina), permitía al lector interpretar la situación expuesta.

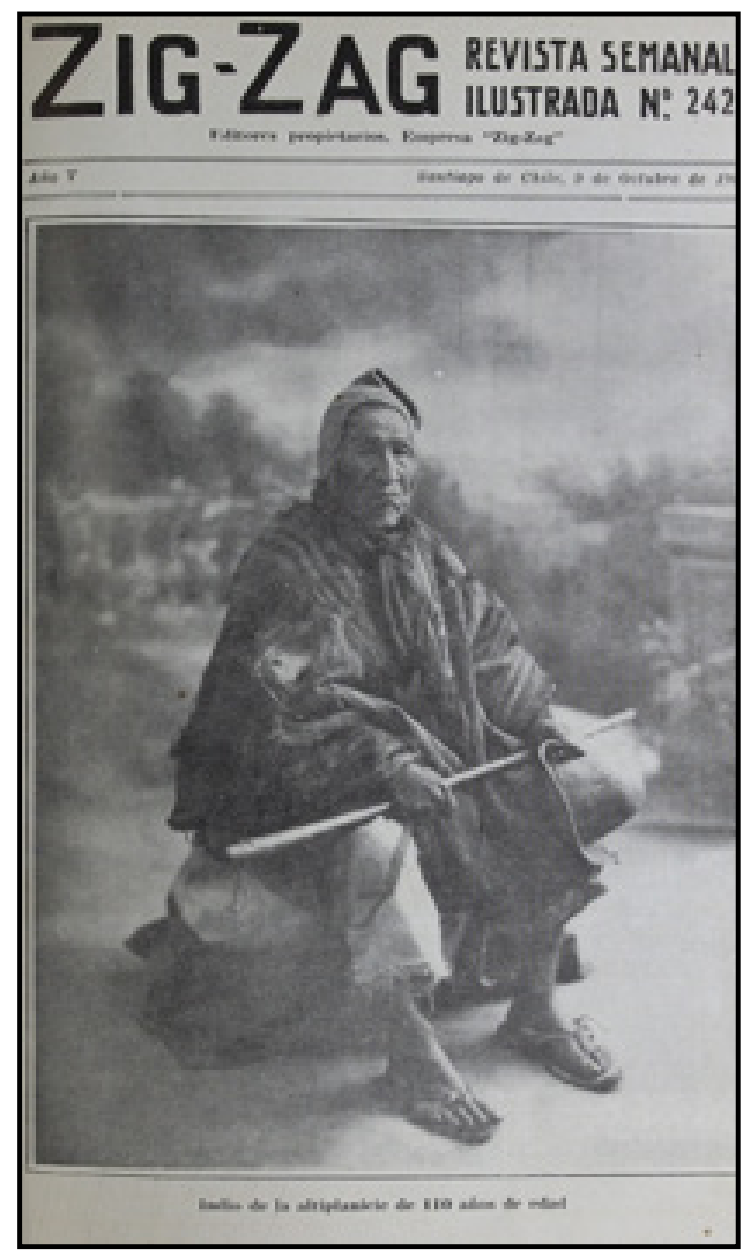

Figura 9. "Indio de la altiplanicie de 110 años de edad". Revista Zig-Zag núm. 242, 9 octubre 1909. 
A modo de ejemplo, la imagen utilizada en la Figura 1 no correspondería a indígenas tacneńos (al menos la fotografía del anciano retratado), sino que ella reproduce un conocido retrato "Anciano aymara", de autoría del destacado fotógrafo arequipeño Max T. Vargas (Garay y Villacorta, 2012). El retrato en cuestión se hizo conocido en el Perú el año 1910 cuando lo publicara la revista Ilustración Peruana. Vargas en esta toma tuvo el particular cuidado de poner en relieve la fotogenia de un sujeto que no requería de un detallado tratamiento para retratarse, una suerte de delicadeza del autor que habría tenido como intención exaltar la dignidad india en un retrato (Garay y Villacorta, 2012, 2016).

Max T. Vargas hizo circular sus fotografías de motivos andinos desde inicios del siglo XX, lo que puede explicar que otros las hayan utilizado para diferentes fines (Garay, com. pers., 2016), situación que nos permite entender la temprana aparición del mismo anciano en la edición 242 del 9 de octubre de 1909 de Zig-Zag (Figura 9). ${ }^{7}$ Algo similar ocurre con los retratos andinos realizados por el fotógrafo Luigi Gismondi (Querejazu, 2009, 2016), que también circularon en los magazines Zig-Zag 700 del 20 de julio de 1918 "Tipo de indio de la altiplanicie boliviana” y 704 del 17 de agosto de 1918 "India boliviana aimara".

El trasfondo artístico que poseen las fotografías de Vargas y Gismondi, reflejado en el preciosismo de sus registros, contrasta con el uso de la imagen dado por la editorial Zig-Zag, considerando que "Tipos tacneńos" suprime todo el cuidadoso contexto del retrato otorgado por Max T. Vargas al "Anciano aymara" (ambiente, telón de fondo, cuidada iluminación y dirección artística; Figura 9) para concentrarse en el rostro consternado del sujeto, desentendiéndose de la intención fotográfica y obviando la humanidad que hay detrás de ella, transformando al retratado en un individuo anónimo acompañando un texto ofensivo.

7 N. del E. La fotografía en cuestión habría sido realizada en la ciudad de La Paz entre 1905 y 1910. Max T. Vargas usó ese fondo exclusivamente en las sesiones realizadas en esta ciudad.
Este uso de la imagen desentendida de su dimensión artística, incluso omite completamente la autoría de esta ("Tipos tacneńos" es atribuida al "corresponsal fotográfico, Sr. Gutiérrez”) dando cuenta del poco interés respecto del trasfondo tras la imagen y su producción, así como del sujeto y situación fotografiada, solo importando el mensaje final ofensivo o alterizador que manifiestan tanto la editorial como el corresponsal.

\section{El norte andino retrasado, desolado y primitivo}

Un elemento recurrente en la aparición del norte en los medios guarda relación con la proyección virtuosa de la imagen de Chile a comienzos del siglo XX como país creciente, moderno y realizador de importantes obras públicas a nivel nacional (Cornejo, 2012; Dümmer, 2014; Leiva, 2015; Ruz et al., 2016). Un país vencedor de una guerra, ejecutor de una fuerte inversión pública e impulsor de importantes procesos de industrialización en regiones a propósito de la inclusión a su erario de los excedentes de la industria salitrera y la exploración $-\mathrm{y}$ explotación- de otros recursos.

$\mathrm{Al}$ igual que en el punto anterior, el sentido de lo expuesto en los magazines $Z i g$-Zag se otorga mediante la permanente oposición entre los aspectos modernizadores predominantes en el discurso nacional chileno y destacados en los magazines (Ruz et al., 2016) en oposición a la tradición nortina.

Esto se observa en reportajes como "Las ciudades muertas", publicado en Zig-Zag en enero de 1928, en donde se presenta al norte como un espacio atado a un tiempo pasado "muerto", "desgajado y "azotado" por el tiempo. Su representación visual recoge la idea de un paisaje descampado, agreste, hostil, desértico y humanamente ruinoso (Figuras 10 y 11). 


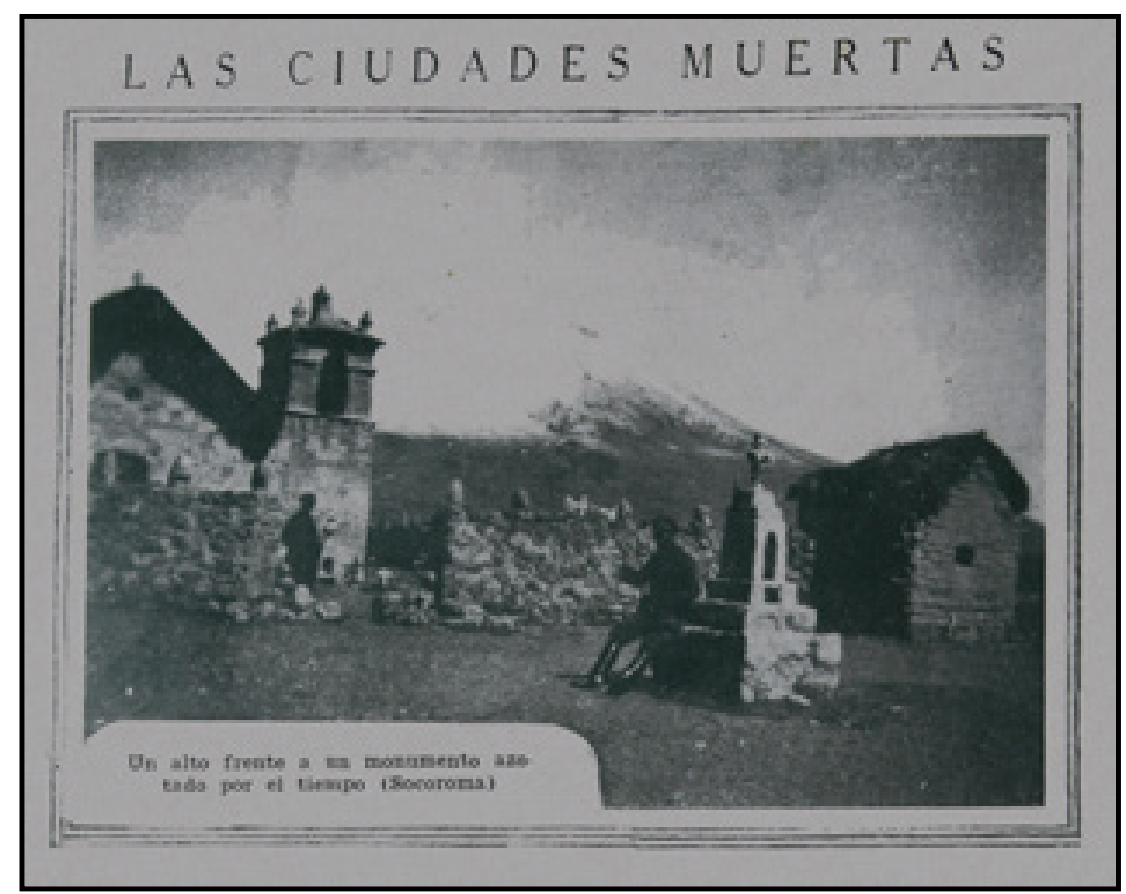

Figura 10. "Las ciudades muertas". Revista Zig-Zag núm. 1196, 28 enero 1928.

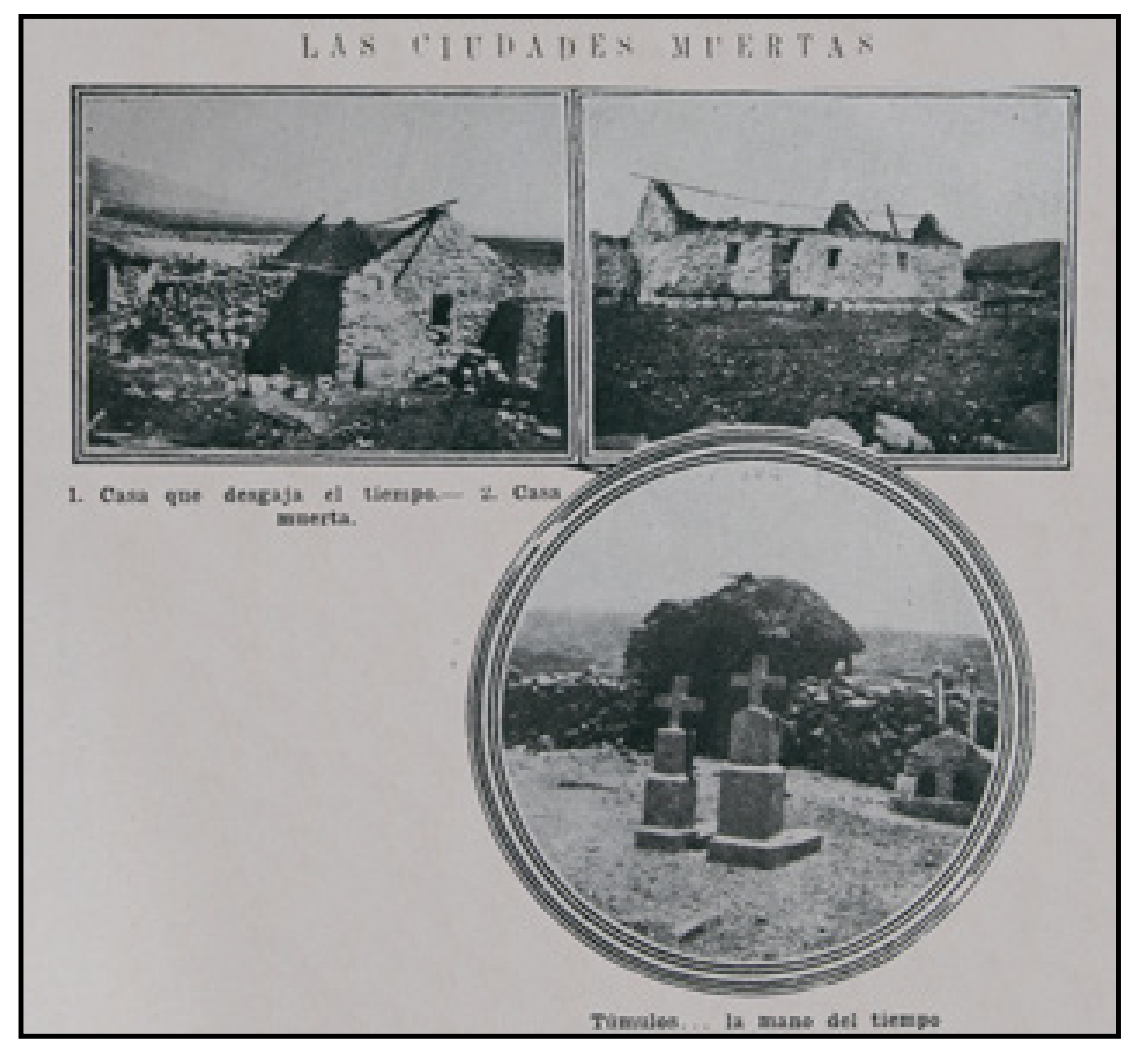

Figura 11. "Las ciudades muertas”. Revista Zig-Zag núm. 1196, 28 enero 1928. 
Se trasmite la idea de poblados tradicionales abandonados con muy poca vida, elementos poco sintonizados con otras expresiones y momentos del diario andar de la comunidades en los sectores precordilleranos y altiplánicos, como por ejemplo sus festividades, la vida campesina y productiva, la vida familiar, la complejidad de sus relaciones económicas y sociales, las que no fueron visibles por los reporteros, que de registrarse se presentan como expresiones de "otros tiempos" y rayando en la incivilización (Figura 12). Esta situación es explícita en el reportaje "En el valle de Lluta", aparecido en Zig-Zag el 17 de febrero de 1907, en donde el reportero anónimo informa sobre la celebración de la fiesta de las cruces en la localidad de Molinos (Lluta) y la participación de bailes morenos, realizando una descripción donde asocia las expresiones de danza y música a "costumbres que prevalecen aun con toda su primitiva fuerza [...] característica mas jenuina de lo que es el espíritu relijioso de aquellos indios o mestizos que, por cierto aun no tienen mucho de civilizados".

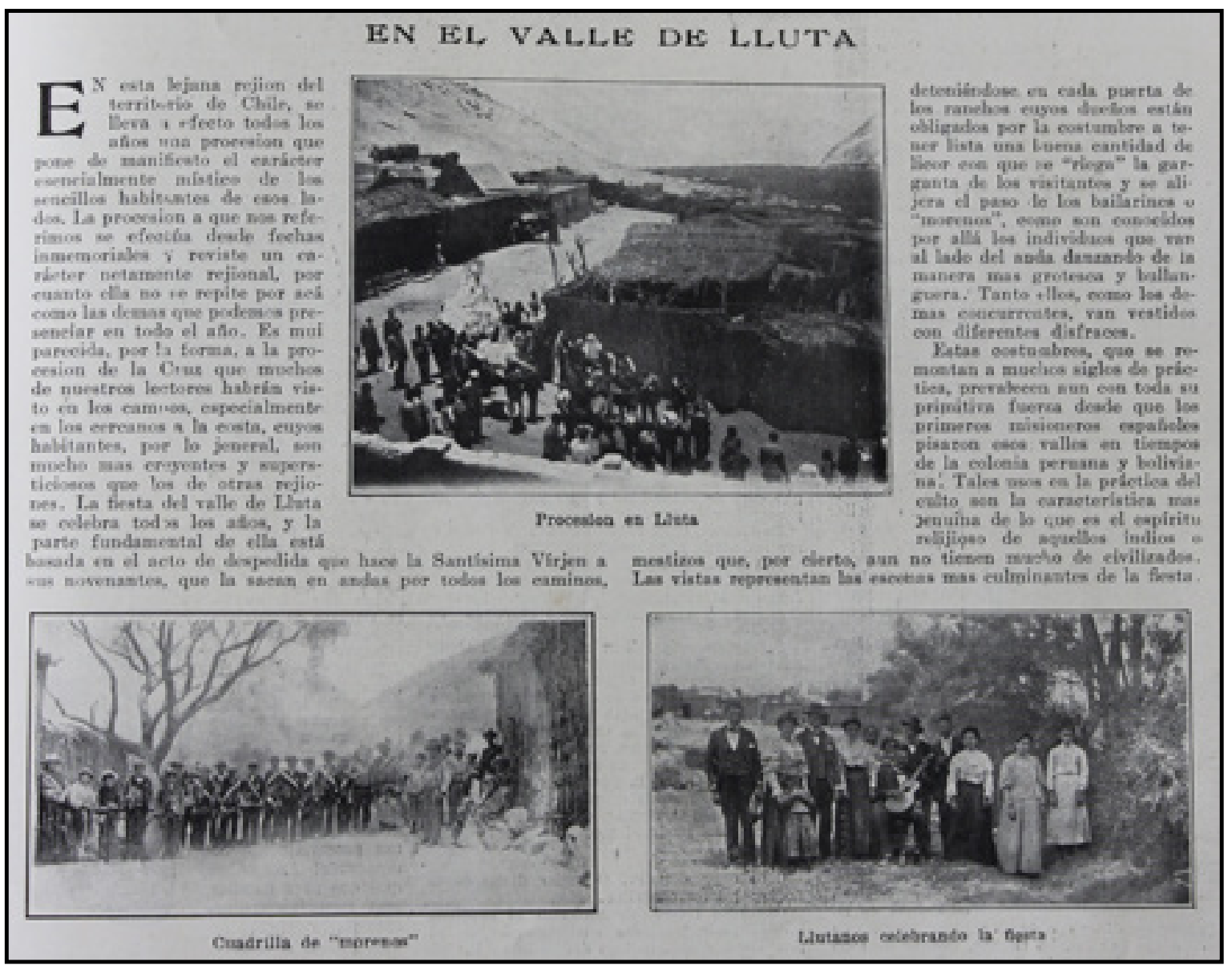

Figura 12. "En el valle de Lluta”. Revista Zig-Zag núm. 104, 17 febrero 1907.

En general en los reportajes predomina la escasa profundización en el conocimiento de los espacios reportados, siendo frecuentes las erráticas referencias geográficas y desajustes entre la "realidad" y lo que se representa en imagen y texto. A modo de ejemplo, la Figura 10, "Un alto frente a un monumento azotado por el tiempo (Socoroma)", se acompaña de su correspondiente referencia textual: "Socoroma es el nombre de otro lugarejo que va siendo abandonado gradualmente; está situada a 3.080 metros sobre el nivel del mar y es tal el enrarecimiento del aire que no lo resisten ni los naturales". Sin embargo, a ojos de un buen observador o conocedor de la zona, se evidencia un error referencial ya que el poblado fotografiado es el pueblo altiplánico de "Tacora" y no el precordillerano poblado de "Socoroma". 
Se puede inferir de lo anterior que no es significativo el contenido del reportaje, sino que importa transmitir un mensaje que dé cuenta de los aspectos negativos de la experiencia en los espacios visitados, o bien la intención de representarlos negativamente.

\section{El fatalismo indígena, su melancolía y desadaptación}

A la desolación y el retraso respecto al espacio geográfico mencionado en el punto anterior se suma una visión del aspecto humano del indígena muy en sintonía con el entorno solitario y oscuro del espacio serrano en el que este se desenvuelve.

La distancia y barrera cultural entre el reportero y lo reportado adquiere tonos de drama al adjudicar el tenor sombrío y melancólico a la población andina, poseedora de un carácter fatalista resultado de su desajuste respecto de la modernidad y progreso impulsado por un modo "occidental". Desadaptación que supuestamente proyectaría una dificultad en cuanto "sobrevivir" a un escenario distinto, situando al tipo desadaptado en una condición de vida ensońada entre el pasado y presente, prevaleciendo el anclaje al pasado, desadaptado al cambio, poniendo al indígena en una condición tránsito-temporal ahistórica, sin presente ni futuro.

El reportaje "Las maniobras de la brigada combinada de Tacna", circulante en Zig-Zag el 15 de diciembre de 1923, grafica esta situación de manera algo implícita, al exponer en imagen al capitán don Manuel Campos acompańado de una indígena, de la cual se asegura tendría "más de cien años", afirmando además que "el aspecto de esta mujer es el de un principio de momificación” (Figura 13). La foto contrapone la imagen gallarda, pulcra y robusta del soldado con aquella anónima de la mujer anciana sin rostro ni rastro de vitalidad, lo que se corona con la asociación del cronista vinculando el aspecto de la mujer con la de restos momificados, aunque en vida.

La relevante fotografía "Anciano aymara" de Max T. Vargas ya citada y publicada en Zig-Zag bajo el rótulo "Indio de la altiplanicie de 110 ańos de edad" (Figura 8) fue acompañada de una interesante reflexión atribuida al cronista de la revista, K.U. Cano quien,

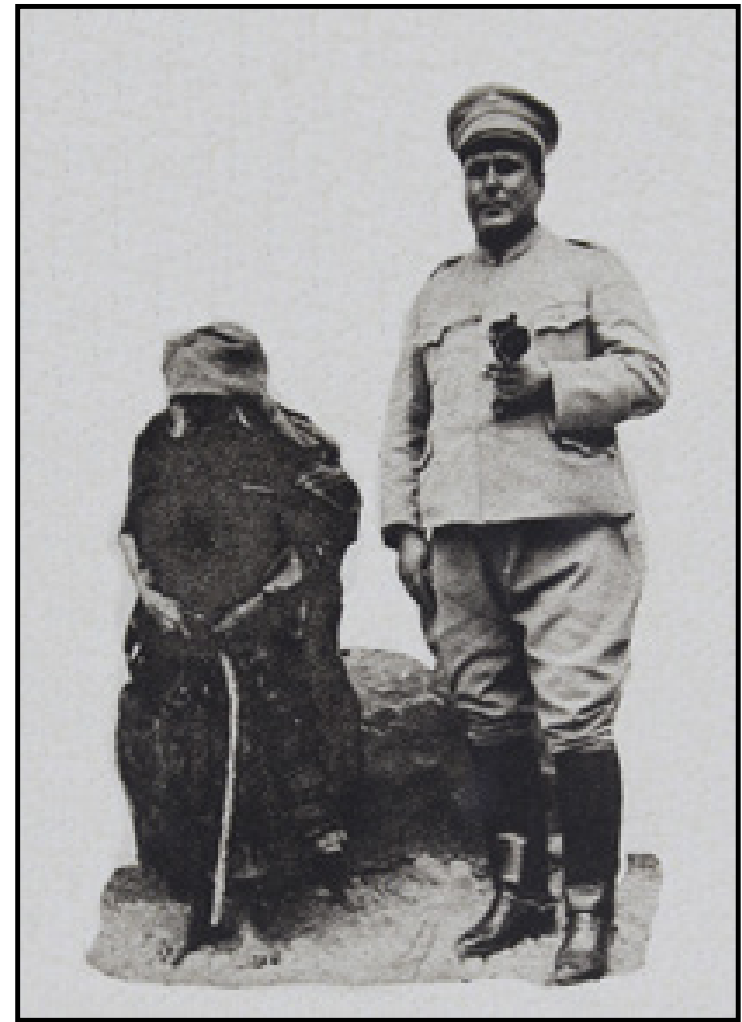

Figura 13. "Las maniobras de la brigada combinada de Tacna”. Revista Zig-Zag núm. 982, 15 diciembre 1923.

tal vez inspirado por la potente imagen, cavila sobre el pueblo aymara refiriéndose al origen de su talante y seńalando que

[...] en ninguna de las otras razas congéneres pobladoras de Méjico y Perú, esté más latente el dolor de la conquista ni más persistente el espíritu que la infundió. El indio es allí de una intensidad de tristeza y melancolía tan honda, de un tan infinito dolor en el rostro, de un tan enorme cansancio y pesar, que pienso que el escoplo del artista de la línea hallaría un sin igual motivo para la esteriorización plástica del dolor humano. En esos grandes ojos negros duerme tu enigma de una angustia sin orillas, de una amargura medrosa y suplicante. En esas pupilas desoladas se retrata el paisaje que vieron de largo tiempo: la pampa inclemente y vasta, el sortilegio turbador de las cumbres blancas y graves [...] en sus labios no fulge el oro de la alegría. 
El fotorreportaje "Ciudades muertas" de 1928 expone una imagen de niños que posan alegres y sonrientes en un parabién (Figura 14); la fotografía se acompaña de un texto que resalta su candidez e inocencia, pero que finalmente deja entrever en tono irónico la escasa posibilidad de los infantes de entender el mundo en el que se desenvuelven, apelando a su condición étnica; el texto describe a "los indiecitos que sonrien [sic] porque no conocen otra vida, creen que el mundo es así... tan malo”.

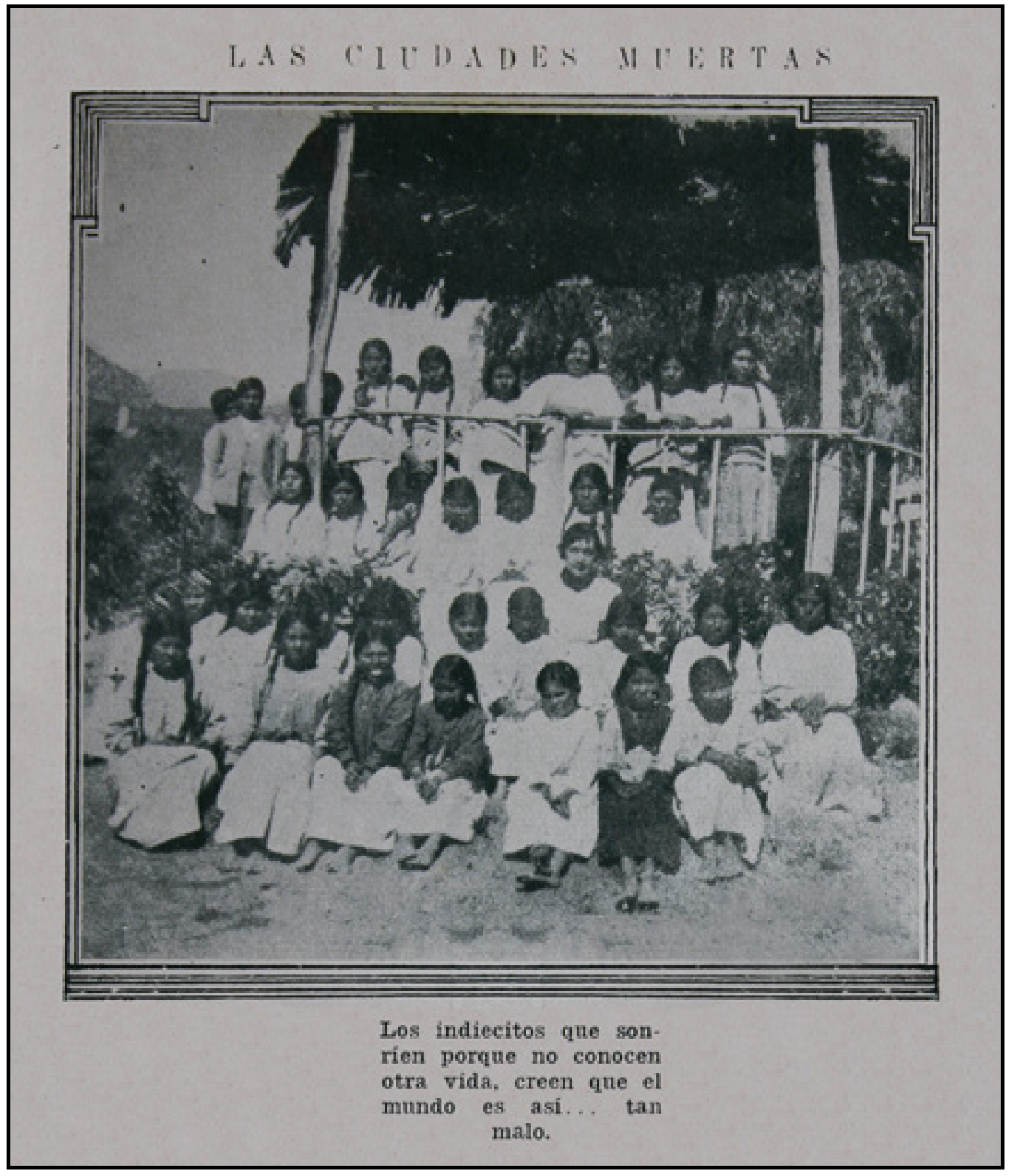

Figura 14. "Las ciudades muertas”. Revista Zig-Zag núm. 1196, 28 enero 1928. 


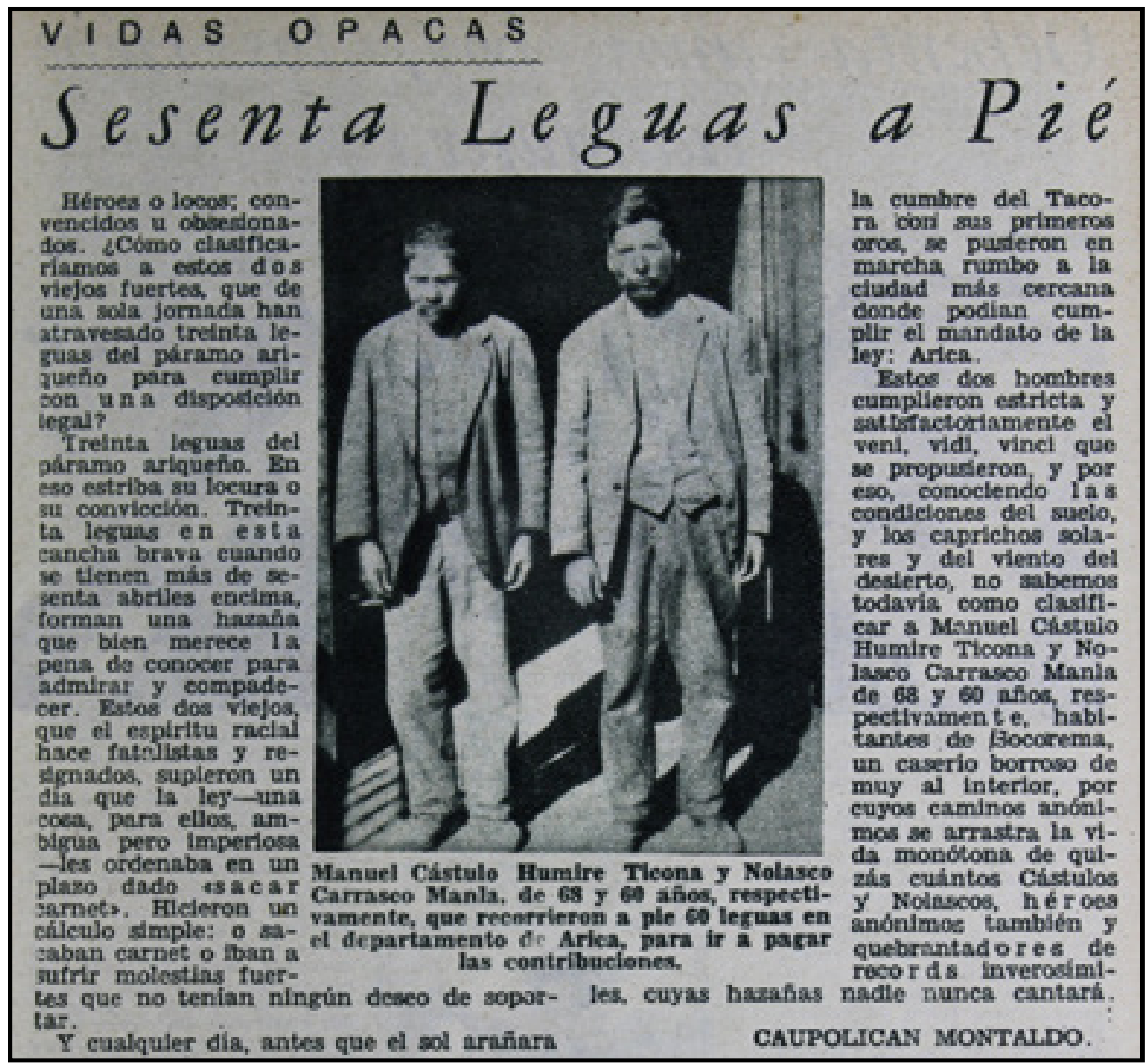

Figura 15. "Vidas Opacas. Sesenta leguas a pie”. Revista Sucesos núm. 142, 13 febrero 1930.

\section{Comentarios finales}

En la edición del 13 de febrero de 1930, Sucesos publica la nota del reportero Caupolicán Montaldo (Figura 15) titulada "Vidas Opacas. Sesenta leguas a pie" en la que se cubre una "extraña" noticia: dos pobladores socoromeños, Manuel Humire y Nolasco Carrasco, recorrieron a pie las sesenta leguas que separan Socoroma de Arica con el propósito de obtener su carné de identidad.

La nota se concentra en el tenor casi épico de la acción. "Héroes o locos, convencidos u obsesionados ¿Cómo clasificaríamos a estos dos viejos fuertes, que de una sola jornada han atravesado treinta leguas del páramo ariqueño para cumplir con una disposición legal?", épica que se ve fortalecida por la supuesta condición adversa de los involucrados tratándose de sujetos andinos que enfrentan una también supuesta legalidad incomprendida. Sucesos asigna atributos negativos a Manuel y Nolasco apelando su condición de raza al señalar que "estos dos viejos que el espíritu racial hace fatalistas y resignados" comprendieron que para la legislación chilena "una cosa para ellos ambigua, pero imperiosa" ordenaba el pago de contribuciones y el obtener un documento identificatorio (carné).

El tono del reportaje, si bien posee una connotación negativarespectodelossujetosrepresentados, también mira con ojos de cierta candidez a quienes hicieron el esfuerzo por responder positivamente al imperativo ciudadano de contar con un registro de identidad. Esta nota despliega un elemento concluyente 
que guarda relación con una concepción del espacio nortino construido desde la distancia con respecto al pulso local y desde los valores culturales de la sociedad indígena regional; aspectos que son disminuidos, menospreciados y observados como "extraños" frente al imperativo nacional "chileno" que se perfila íntegro, opuesto a la precariedad y carencia con que se representa al mundo indígena.

El despliegue y difusión del relato virtuoso nacional presenta al indígena como desajustado al paradigma modernizador y occidental chileno, mostrándolo como "carente de civilización", necesitando para alcanzar este estadio superior de un disciplinamiento que lo conduzca al progreso, orden, legalidad y bienestar material (Ruz et al., 2016).

Las narraciones periodísticas vehiculizadas en los magazines de la editorial Zig-Zag reproducen la impronta cultural de una nación, al mirar u observar a un otro desde una percepción metropolitana y urbana chileno-central desconocedora y alterizadora de la realidad regional nortina. Así el imaginario construido desde el prejuicio y los presupuestos (la fealdad, el retraso, el primitivismo, el fatalismo, la desadaptación) se explican en función de un discurso dominante proveniente de un interlocutor representado por un supuesto Chile moderno y en progreso hacia comienzos del siglo XX.

\section{Agradecimientos}

Resultado de Proyecto FONDECYT 1151514 y 1171499. Proyecto de Investigación Mayor de Ciencia y Tecnología UTA 5749-17. Expresamos nuestro agradecimiento al Convenio de Desempeño en Educación Superior Regional UTA 1401, financiado por el Ministerio de Educación y la Universidad de Tarapacá.

\section{Referencias citadas}

Alvarado, M. (2016). Sujetos, paisaje e imaginarios de frontera en el norte de Chile. Construcción visual/fotográfica del indígena del desierto y el altiplano. Diálogo Andino, 50, 21-44.
Alvarado, M. y Möller, C. (2011). Memoria visual e imaginarios. Fotografías de pueblos originarios. Siglos XIXXXI. En Alvarado, M. y Möller, C. (Eds.). Memoria visual e imaginarios (pp. 9-12). Santiago: Pehuén.

Alvarado, M. y Möller, C. (2012). Fuera del cuadro. Representación y alteridad en la fotografía del indígena del desierto y el altiplano. En Alvarado, M., Mege, P., Bajas, M. y Möller, C. (Eds.). Andinos. Fotografías siglos XIX y $X X$. Visualidades e imaginarios del desierto y el altiplano (pp. 23-40). Santiago: Pehuén.

Angenot, M. (2010). El Discurso Social. Limites históricos de lo Decible y lo Pensable. Buenos Aires: Siglo XXI.

Arellano, J. (2011). Los republicanos en armas: los proscritos, el gobierno y la opinión pública ante la Confederación Perú-Boliviana. Universum, 27, 49-66.

Arellano, J. (2012). Discursos racistas en Chile y Perú durante la Guerra del Pacífico. Estudios Ibero-Americanos, 38(2), 239-264.

Bajas, M. (2016). Fotografías de frontera en el Norte Grande de Chile (1900-1970). Diálogo Andino, 50, 45-58.

Bajas, M. y Mege, P. (2012). Paradigma visual del indígena del desierto y el altiplano. Antropología de la fotografía. En Alvarado, M., Mege, P., Bajas, M. y Möller, C. (Eds.). Andinos. Fotografias siglos XIX y XX. Visualidades e imaginarios del desierto y el altiplano (pp. 41-52). Santiago: Pehuén.

Barthes, R. (1986). Lo obvio y lo obtuso. Imágenes, gestos, voces. Barcelona: Paidós.

Cid, G. (2009). Un ícono funcional: La invención del roto como símbolo nacional, 1870-1888. En Cid, G. y San Francisco, A. (Eds.). Nación y Nacionalismo en Chile. Siglo XIX (pp. 221-254). Santiago: Centro de Estudios Bicentenario.

Cornejo, T. (2012). Fotografía como factor de modernidad: territorio, trabajo y trabajadores en el cambio de siglo. Historia, 45(I), 5-48.

Dümmer, S. (2014). Metáforas de un país frío. Chile en la Exposición Iberoamericana de Sevilla en 1929. En Peliowski, A. y Valdés, C. (Eds.). Una geografía imaginada: diez ensayos sobre arte y naturaleza (pp. 169-188). Santiago: Metales Pesados. 
Freund, G. (2014). La fotografía como documento social. Barcelona: Gustavo Gili.

Galdames, L., Ruz, R. y Meza, M. (2014). Imaginario nacional en revistas de la frontera norte de Chile post Guerra del Pacífico Ariqueña (Arica, 1923) y Torbellino (Tacna, 1924). Interciencia, 39(7), 490-494.

Garay, A. y Villacorta, J. (2012). Un arte arequipeño: maestros del retrato fotográfico. Lima: Instituto Cultural Peruano Norteamericano de Lima.

Garay, A. y Villacorta, J. (2016). El origen y desarrollo de la noción de "Reportero Gráfico" en el Perú y la visualidad del territorio a inicios del siglo XX. Diálogo Andino, 50, 99-113.

García Huidobro, C. y Escobar, P. (2012). Una historia de las revistas chilenas. Santiago: Ediciones Universidad Diego Portales.

Hall, S. (1997). Representation: cultural representation and signifying practices. Londres: Thousand Oaks.

Hobsbawm, E. y Ranger, T. (2002). Invención de la tradición. Barcelona: Crítica.

Ibarra, P. (2015). El Perú y Bolivia ante el General Pililo: los enemigos de Chile en las caricaturas de la Guerra del Pacífico (1879-1883). Diálogo Andino, 48, 85-95.

Krotz, E. (1994). Alteridad y pregunta antropológica. Alteridades, $4(8), 5-11$

Larraín, J. (2008). Identidad chilena. Santiago: LOM.

Leiva, G. (2015). Las transformaciones modernas de la fotografía en Chile: Visibilizados/invisibilizados (18401925). Orda, 219, 2-15.

Maturana, F. (2012). Discursos visuales hegemónicos y de resistencia. El caso de la representación fotográfica aymara en Chile. En Alvarado, M., Mege, P., Bajas, M. y Möller, C. (Eds.). Andinos. Fotografías siglos XIX y XX. Visualidades e imaginarios del desierto y el altiplano (pp. 53-68). Santiago: Pehuén.

McEvoy, C. (2007). ¿República nacional o república continental? El discurso republicano durante la Guerra del Pacífico, 1879-1884. En McEvoy, C. y Stuven, A. (Eds.). La república peregrina. Hombres de armas y letras en Amé- rica del Sur, 1800-1884 (pp. 531-562). Lima: Instituto de Estudios Peruanos - Instituto Francés de Estudios Andinos.

McEvoy, C. (2010). Armas de persuasión masiva. Retórica y ritual en la Guerra del Pacífico. Santiago: Centro de Estudios Bicentenario.

McEvoy, C. (2012a). Guerreros Civilizadores. Santiago: Ediciones Universidad Diego Portales.

McEvoy, C. 2012b). Civilización, masculinidad y superioridad racial. Una aproximación al discurso republicano chileno durante la Guerra del Pacífico (1879-1884). Revista de sociología politica, 20(42), 73-92.

Montealegre, J. (2008). Historia del Humor Gráfico en Chile. Madrid: Milenio.

Ossandón, C. y Santa Cruz, E. (2005). El Estallido de las Formas. Chile en los Albores de la "Cultura de Masas". Santiago: LOM.

Palacios, N. (1904). Raza chilena. Un libro escrito por un chileno y para los chilenos. Valparaíso: Imprenta y litografía alemana.

Querejazu, P. (2009). Luigi Doménico Gismondi. Un fotógrafo italiano en La Paz. La Paz: Fautapo.

Querejazu, P. (2016). Miradas desde la otredad: la construcción de la imagen de Bolivia en la obra fotográfica de Luigi Doménico Gismondi. Diálogo Andino, 50, 74-84.

Ribas, A. y Cortés, J. (1998). Para medir el espíritu de época. El Ciervo, 47 (562), 11-15.

Rinke, S. (2002). Cultura de masas: reforma y nacionalismo en Chile 1910-1931. Santiago: Dibam.

Rubilar, M. (2010). Escritos por chilenos, para los chilenos y en contra de los peruanos. La prensa y el periodismo durante la Guerra del Pacífico. En Donoso, C. y Serrano, G. (Eds.). Chile y la Guerra del Pacífico (pp. 39-74). Santiago: Centro de Estudios Bicentenario.

Ruz, R., Galdames, L. y Díaz, A. (2015). Alterización del Perú negro en magazines chilenos: Corre Vuela 19101930. Interciencia, 40(11), 799-805. 
Ruz, R., Galdames, L., Díaz, A. y Meza, M. (2016). Relatos visuales de una Arica chilena. Los magazines de la editorial Zig-Zag (1902-1930). Diálogo Andino, 50, 115-132.

Santa Cruz, E. (2002). Modernización y cultura de masas en el Chile de principios del siglo veinte: el origen del género magazine. Comunicación y medios, 13, 169-184.

Skuban, W. (2007). Lines in the Sand: Nationalism and Identity on the Peruvian-Chilean Frontier. Alburquerque, NM: University of New Mexico.

Smith, A. (2000). ¿¿Gastronomía o geología? El rol del nacionalismo en la reconstrucción de las naciones. En Fernández, A. (Comp.). La invención de la nación. Lecturas de la identidad de Herder a Homi Bhabha (pp. 185-209). Buenos Aires: Manantial.
Subercaseaux, B. (2007). Literatura, nación y nacionalismo. Revista chilena de literatura, 70, 5-37.

Subercaseaux, B. (2010). Raza y Nación: ideas operantes y políticas públicas en Chile, 1900-1940. En Cid, G. y San Francisco, A. (Eds.). Nación y Nacionalismo en Chile. Siglo XIX (pp. 221-254). Santiago: Centro de Estudios Bicentenario. 
